\title{
Research of Students' Attitudes toward the Management Challenges at Private and State Universities
}

\author{
Ekaterine Gulua \\ PhD in Economics, Manager of HPML, Assistant-Professor of TSU \\ Tea Kasradze \\ $\mathrm{PhD}$ in Economics, Professor of CIU, Head of BA PhD Program \\ Nino Zarnadze \\ $\mathrm{PhD}$ in Economics, Associate Professor of $\mathrm{CIU}$
}

\begin{abstract}
The research refers to the study management mechanisms of tertiary education institutions. Specifically, the research discusses management peculiarities at private and state universities, their strengths and weaknesses, opportunities and threats. The thesis examines both the challenges of teaching process management and infrastructure issues as well as the relevant legislative and normative frameworks that are the basis of the functioning of the organization. Ongoing reforms, achievements and challenges of the tertiary education system in Georgia are also reviewed in the article. Research was conducted in 2019 to analyze the above-mentioned issue in depth at one state and one private university. 342 students in total have been interviewed. The faculty of Economics and Business was selected for piloting, as almost all multi-profile private and state universities have this faculty. Focus-group Methodology was used to interview the students. 36 closed ended (multiple choice questions) and one open ended questions were included in the questioniar. We studied students' attitude to the learning process, programs, professors' skills, and level of students' trust to the university, whether they believe that they will get modern knowledge and will be able to engage in the global competition after graduating from the university. During the research we were interested how fascinating was the scientific work for the students - young generation, whether they wish to become lecturers, scientists, what challenges they see along this path and in general how they appreciate their professional choices. We were interested in the attitude of the students toward the current situation in management. Do they feel bureaucratic barriers and gaps in the university governance? We were also interested in how the students value their life at the university, whether they like the university infrastructure. The study shows a very positive attitude of private university students toward their university. Quantitative and qualitative research has enabled us to identify existing challenges and develop relevant recommendations.
\end{abstract}

Keywords: Public universities, Private universities, Tertuary Education System, Research of Students Attitude

\section{Introduction}

The trends of university management changes in 2020 are due to social (personal and social effectiveness of individuals), technological (impact of techniques, software and technologies on society), economic (influence of mega, macro and micro trends on work and skills needed) (Tea, Kasradze, 2013), environmental (surroundings and its sustainability - workplace, city and place of residence are meant in it) and political (state policy, government systems, decisions and society) factors [19] (Tea Kasradze, Nino Zarnadze, 2019).

After receiving a secondary education, people who wish to pursue further education are faced with the difficult decision of continuing their studies at a private or at a state (public) higher education institution. On the one hand, there are state universities with relatively low prices and many years of teaching experience, on the other hand, private universities with high fees, good infrastructure and less teaching experience. It is interesting to see if the expectations of the students are 
justified after making choices. Do they even have the feeling that they are acquiring modern, market-oriented competitive knowledge? (Kasradze Tea; Zarnadze Nino, 2018).

The Lisbon Declaration of the European University Association [20] says: „Europe now expects its universities to perform an even wider role, enabling civil society to meet the challenges of the twenty-first century. Climate change, energy issues, increasing longevity, the rapid pace of technological change, growing global interdependence and rising economic inequality both within Europe and between Europe and other continents: all these require investigation, fundamental research as well as technological and social innovation which will solve problems as they arise and ensure economic success combined with social stability in many different societies" (Europe's Universities beyond 2010: Diversity with a Common Purpose, 2010).

The Declaration, on the one hand, calls on governments to increase education funding, emphasizing the role of adequate funding to secure the future of universities, enhancing their social, cultural and technological skills. It says the education system will not be complete until research funding is seen as a future investment (Kasradze Tea, 2014) (Kasradze Tea, 2014). On the other hand, it calls on universities to improve their governance structures and leadership competencies in order to enhance their effectiveness, innovative capabilities and achieve their multifaceted mission.

The Declaration places fundamental importance on the issue of university autonomy. Autonomy implies the independent management and control of property, staff and finances, as well as accountability to the internal university community.

It is interesting to see how Georgian universities are prepared to respond to these challenges.

Before gaining the independence, there were only state universities in Georgia. After the independence, the number of HEls increased significantly, but this was mainly due to the emergence of private institutions on the market. By the beginning of 2019, there were 44 private and 19 public (state) higher education institutions in Georgia. The number of private HEls was on the rise over the years, but in 2019 their number decreased by 12 units compared to the previous year. The majority of higher education institutions, $62 \%$, is in Tbilisi [21] (Diagram 1) [22].

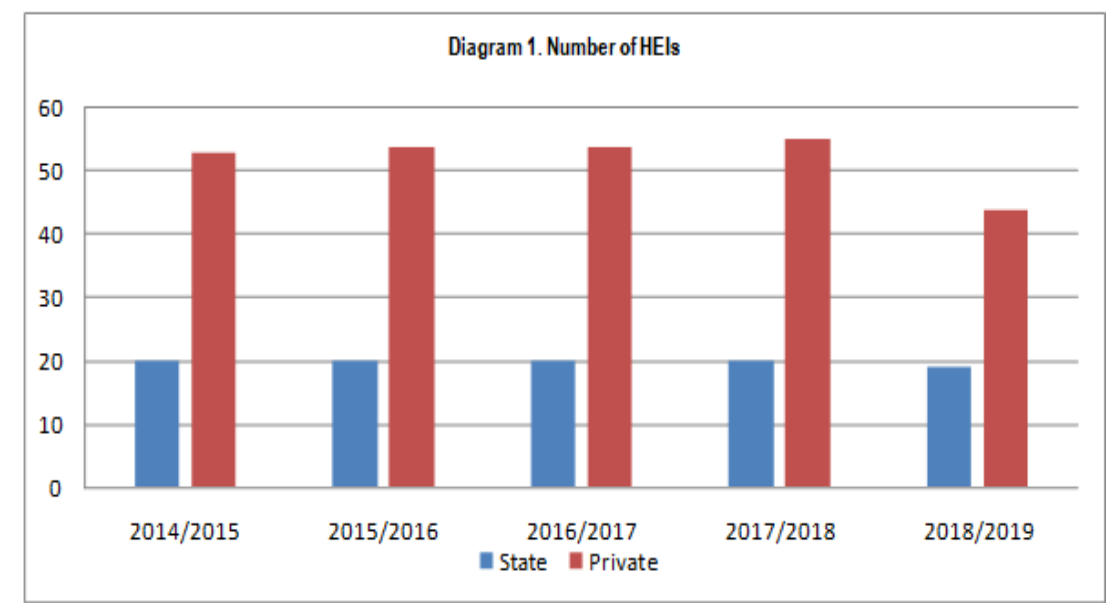

By the beginning of the 2018/2019 academic year, 41.6 thousand students were enrolled in Georgian higher education institutions, out of which 27.8 thousand are at state universities and 13.8 thousand at private universities. Student admissions are decreased by 2.700 compared to the last year. The decline happens mainly at private universities. The total number of students at Georgian higher education institutions amounted to 147.7 thousand, which is $2.7 \%$ more than in the previous academic year. $65 \%$ of the students study at state higher education institutions and $35 \%$ at private schools. $50.2 \%$ of the students are female and $49.8 \%$ are male. [21] (Diagram 2) 


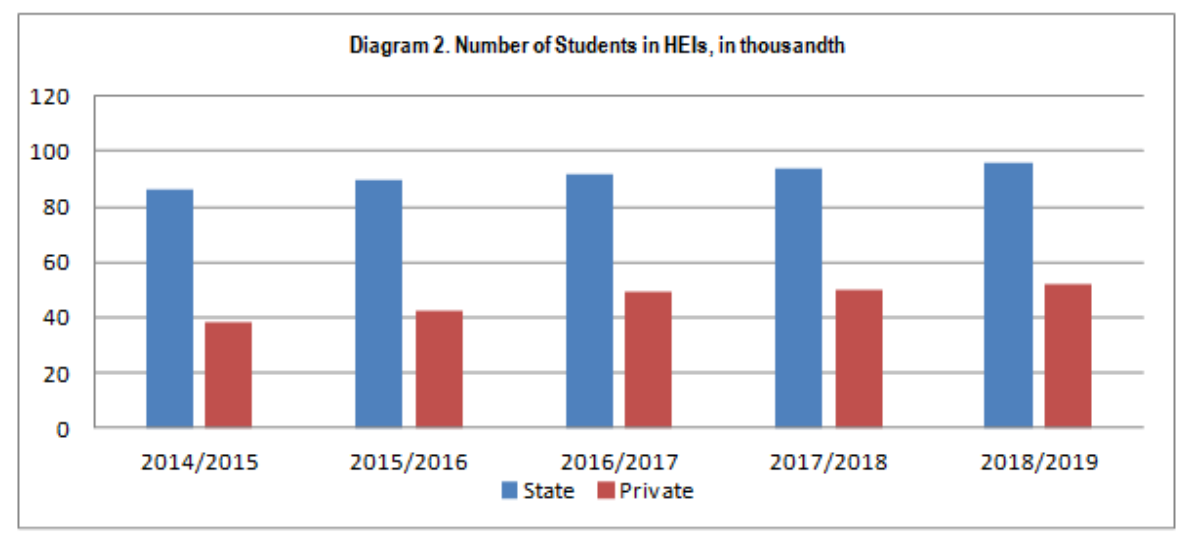

According to the number of enrolled students the list of the top ten universities of Georgia in 2018 looks like this:

1. Ivane Javakhishvilis Tbilisi State University (Tbilsi) - 4432 Students

2. Georgian Technical University (Tbilsi) - 3885 Students

3. llia State University (Tbilsi) - 3571 Students

4. Akaki Tsereteli State University (Qutaisi) - 1655 Students

5. Georgian National University (SEU) (Tbilsi) - 1623 Students

6. Batumi Shota Rustaveli State University (Batumi) - 1317 Students

7. Georgian University (Tbilsi) - 1288 Students

8. Tbilisi State Medical University (TSMU) (Tbilsi) - 1017 Students

9. Caucasus University (Tbilsi) - 1006 Students

10. Business and Technology University (Tbilsi) - 917 Students [22].

Out of which there are 6 state universities and exactly they are in the first four places. While according to the number of students enrolled with the scaled points private universities are on the top. Specifically, according to the number of enrolled students the list of top ten universities in 2018 in Georgia looks like this:

1. Free University (Tbilsi) - Average Scalar Score: 2115.78

2.Agricultural University of Georgia (Tbilsi) - Average Scalar Score: 2022.44

3. Tbilisi State Medical University (TSMU) (Tbilsi) - Average Scalar Score: 2015.42

4. David Tvildiani Medical University (Tbilsi) - Average Scalar Score: 1967.70

5. Ivane Javakhishvilis Tbilisi State University (Tbilsi) - Average Scalar Score: 1964.58

6.New Vision University (Tbilsi) - Average Scalar Score: 1947.53

7. Caucasus University (Tbilsi) - Average Scalar Score: 1919.15

8. Georgian Institute of Public Affairs (GIPA) (Tbilsi) - Average Scalar Score: 1911.54

9. International Black Sea University (Tbilsi) - Average Scalar Score: 1893.27

10.Business and Technology University (Tbilsi) - Average Scalar Score: 1884.97 [22]. 
How do private and public HEls differ from one another? According to the OECD's glossary, an institution is classified as public if it is controlled and managed directly by a public education authority, or by a governing body most of whose members are appointed by a public authority. Conversely, a private institution is one that is controlled by a nongovernmental organization, or if its governing board consists mostly of members not selected by a government agency [23] George Psacharopoulos the member of the European Experts Network on Economics of Education (EENEE) gives us the similar definition in his work „,who makes the critical decisions regarding the operations of a university: Is it the center, e.g., a bureaucrat in the Ministry of Education? Or is it the university senate and, why not, the student-user of university services?" [24]

If we rely on these definitions, there is really no state or private HEI not only in Georgia but also in many countries around the world. However, it is likely that the state HEl leadership in Georgia according to the number of enrolled students is associated with the state, along with the low tuition fees.

Unlike state HEls, private universities have the potential to be more flexible in terms of market demand, they can concentrate on profitable segments and lower costs on non-profitable processes, such as scientific activities of academic staff. They have less commitment to older professors, as they are more free during choosing staff, and state universities include scientific institutions within their own framework maintaining of which sometimes has a purely social function.

Institutions often fail to provide their own needs. The state or university has to cover the cost of maintaining them. However, the age of private universities in Georgia does not exceed the age of independent Georgia. They have more freedom to attract or fire staff because of not so much scientific achievement as academic skills. Consequently, in most cases, they choose young staff, which allows them to save money. However, Article 34 of the Law on Higher Education [25] obliges all higher education institutions to elect their academic staff on the basis of open competition, in accordance with the principles of transparency, equality and fair competition, which should be determined by their statute.

In Georgia, state universities have such an important advantage as history, the oldest of which - Ivane Javakhishvili Tbilisi State University is 102 years old, although it was created as a joint stock company in the period of Georgia's independence in 1918, since 1921 it has become an object of the Soviet state ownership. Soviet Georgian State Universities owned a large amount of material capital, utilizing all fields of science and education. In independent Georgia many areas have become less attractive for the market, though state universities in line with state policy are trying to maintain unprofitable directions, which commercially damages state universities to some extent, though maintaining them is important for the state and, therefore, the government encourages entrants to maintain such directions, However, maintaining them is a matter for the state, and the government, therefore, encourages entrants to maintain such directions, introducing benefits such as cancellation of payments so that they can choose these directions. Therefore, some universities do not have competitors in some directions on the domestic market. The state also regulates the number of places declared. State universities have the advantage in this regard, they have the opportunity to increase the number of entrants.

It should be noted that the size of student groups at public universities (at most 30 undergraduates per group) exceeds the number of students in private sector groups, which, of course, reduces the chances of applying individual approaches towards students at state universities, especially at multidisciplinary faculties such as Economics and Business and Law Faculties.

Students' rights are, of course, protected by the constitution and law. The Georgian Law on Higher Education [25] (Article 43) grants any student the right to: a) acquire high quality education; b) participate in scientific research; c) use the material and technical and, library and, informational and other resources of a higher education institution on equal terms, as provided for by the statute, and the internal regulations and provisions of the higher education institution;

However, when it comes to applying to a private or state HEI for the exercise of this right, the entrant must know what are the key factors (degree of independence, effective internal and external HEI management mechanisms, access to financial resources, which in turn ensures the proper learning environment with state-of-the-art technology and infrastructure, highly qualified academic staff, etc.) that make them substantially different and affect the quality of student's knowledge acquired at the $\mathrm{HEl}$.

According to Article 15 of the "Law of Georgia on Higher Education" [25] the determination of the management bodies of higher education institutions and their competences is the prerogative of these subjects themselves, which they should state in the Statute. State higher education institutions, in particular, public law legal entities, are required by law to 
administer management through the Academic Council, the Representative Board, the Rector, the Head of Administration, and the Quality Assurance Service.

First, private and state HEls differ in the degree of independence. Both private and public higher education institutions in accordance with Article 10 of the Law on Higher Education:

- Endorse the main areas of study, research and creative activity;

- Develop a statute, approve the institution's internal regulations, the principles and rules of ethics and disciplinary responsibility;

- Approve the unified rules for hiring academic and support staff;

- Elect the institution's management bodies and officials;

- Dispose of its finances and property in the manner prescribed by the legislation of Georgia;

Although, according to the law, in case of the state universities directly the government structures do not make decisions, nor do they appoint the rector directly, but the degree of autonomy and academic freedom is still low. Despite the high autonomy granted by law for the election of a rector, election in fact is formal in state HEls and there are more appointments than elections. The degree of independence is also low at the time of the creation of academic structures, and these structures serve the interests of certain narrow groups. It can be said that the two-step management system is formal and actually authoritarian at public universities [26].

The degree of financial autonomy of state HEls is also low (Kasradze Tea, 2016). Since 2004, direct funding of public HEls by the state in Georgia has been minimized. Today, HEls receive funding from the state not on the basis of the number of students, but on the number of successful students at the Unified National Exams. The rest of the students pay the tuition fee by themselves. Students who have enrolled in private higher education institutions after successfully passing the Unified Entry Exams also receive state grants. State HEls are legally allowed to spend their income from students' funding independently, though funds are scarce because of the limited number of students (students are enrolled through the Unified National Exams and the HEI has no means for choosing them) and tuition fee (2250 GEL), set by the state and they do not have the right to increase it. Whereas, private HEls do not have such a restriction. The current voucher model of financing public and private HEls prevents a healthy competition on the market.

It can be said that it puts some of the private universities in a relatively privileged position. Private and public higher education institutions receive approximately equal numbers of state-funded students, correspondingly, they receive approximately equal funding from the state.

In the absence of basic funding from the state budget, a state tuition grant is the only means of obtaining public funding for public higher education, and since private higher education institutions, unlike public institutions, can impose tuition fees to any extent, their total income significantly exceeds the income of public agencies (up to GEL 8,000).

Existing funding rule at public institutions results in low pay for academic and administrative staff (with the exception of law and economics and business faculties, high salaries are due to a particularly large contingent of students), which does not have a positive impact on the quality of the teaching and learning processes (Kasradze, Tea; Antia , Vakhtang; Gulua, Ekaterine;, 2019).

The biggest challenge for higher education in both public and private universities in Georgia is to establish good governance principles. Good governance implies transparency, accountability, effectiveness, and more. Article 16 of the Law of Georgia on Higher Education obliges HEls to provide:

a) Publicity and accessibility for all interested persons to the decisions of its management bodies, reports and decrees; State-owned non-entrepreneurial (non-commercial) legal entities are subject to the norms of freedom of information established by the General Administrative Code of Georgia [27] This type of institution should have transparent decisionmaking procedures;

b) Academic freedom of academic staff, scientific staff and students;

c) Involvement of academic staff, scientific staff and students in decision-making; 
d) Equal treatment for all, regardless of one's ethnic or social origin, gender, political or religious beliefs, etc.;

e) Fairness and transparency of elections and the publicity of competitions held at a higher education institution;

However, legislative regulation alone is not enough, unfortunately. Quality assurance rather than quantity is a critical issue at private and public universities around the country. With good governance, HEls will be able to better identify limited resources and use internal control mechanisms more effectively. Weak governance (both internal and external) is a major problem that has contributed to the inefficiency and inefficiency of higher education.

It is believed that the model of governance in which the state assumes the role of a supervisor may be better than strict government control, which is somewhat detrimental to higher education in developing countries (Olda, 2007). The state can play an important stimulating, supportive role in reforming and developing higher education institutions (Antia, Vakhtang;, 2018). Direct state control may sometimes be needed to regulate the higher education system in developing countries.

The shortage of good governance and financial resources has a negative impact on the quality of academic staff and HEls' infrastructure, which naturally affects the quality of teaching.

In the field of staffing, both private and public universities have a high autonomy in the selection, dismissal and promotion of staff and in the determination of salaries. However, the extensive rights of universities are, in some cases, ineffective and unfair at public universities.

This process is facilitated by the competition regulations for the selection of academic staff developed by universities, which do not guarantee the fulfillment of the requirements set by law. HEls fail to ensure fairness and transparency of elections and publicity of competitions in higher education. All of this has a significant negative impact on the quality of educational programs and, ultimately, significantly reduces the guarantees of the right to receive a quality education [28].

Academic staff statistics affect the costs of higher education institutions, on the one hand, and its quality, on the other. The overwhelming number of academic staff is declining from year to year in the public sector, while rising in the private sector. At the beginning of 2016-2017 8231 units of professors were reported. $36 \%$ in the private and $64 \%$ in the public sector. This is while $29 \%$ of the total graduates are from the private sector and $71 \%$ from the public sector. This means that more lecturers are for one student in the private sector and less in the public sector (Diagram3) (Kasradze, Tea; Antia , Vakhtang; Gulua, Ekaterine;, 2019).

\title{
Diagram3. Number of Professors in HEls
}

\section{(At the beginning of school year, (persons)}

\author{
Eublic $=$ Private
}

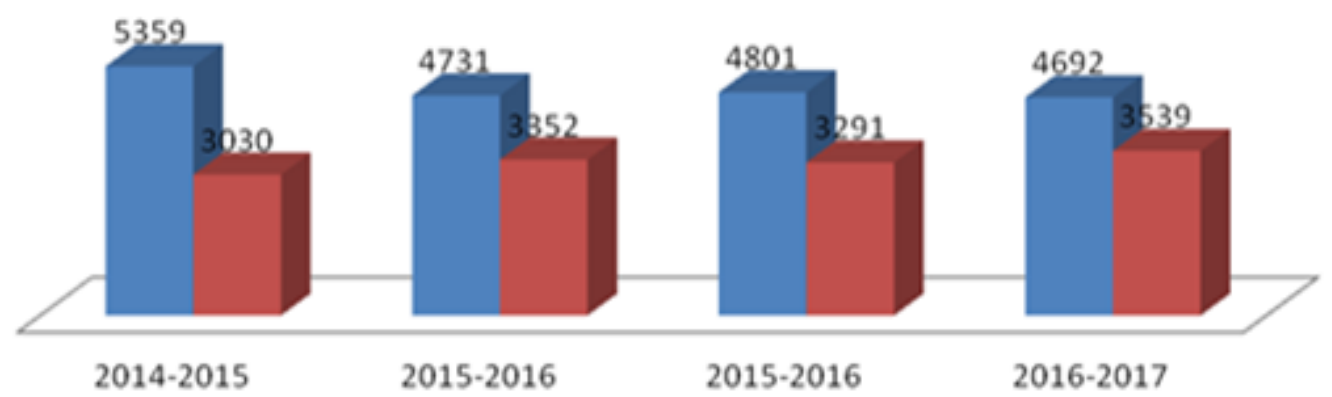

Another key factor for assessing how a university responds to contemporary challenges is its involvement in researches. Research is always regarded as an important aspect of teaching and learning in higher education. Research is related to 
quality. Educational institutions that are not research oriented do not contribute to creating a knowledge-based society (Tea Kasradze, Nino Zarnadze, 2019). Without research, universities will not be able to produce and disseminate new knowledge, and this will hamper national and human development goals (Kasradze Tea, 2018) .

General researches are scarce at both private and public universities and research infrastructure is quite poor and outdated/inadequate. University funds allocated for researches are always less than needed. Most of their budget is spent on salaries and pensions for teachers and other support staff, and small amounts are spent on research.

In 2017, education funding amounted to 137 million GEL, which was $0.36 \%$ of the country's GDP. And for higher education and research altogether, 190 million GEL was allocated in 2017, which is $0.5 \%$ of the country's GDP and $1.62 \%$ of the budget expenditure. Similar figures in 2012 look like this: government spending on higher education and research was also $0.5 \%$ of GDP but it amounted to $1.8 \%$ of the budget, which means that although government spending doubled in 2017 compared to 2013, its share in GDP remained the same and in terms of overall budget, it has even declined. This, unfortunately, indicates that the government cannot provide sufficient funds for universities to research. In 2018, the Research and Development in Georgia were conducted by 56 Institutions, of which 47 were Higher Education Institutions. Total expenditures on R\&D equaled 128.3 Million GEL. Number of employees in Research and Development equaled 15 522 persons, of which 11174 were researchers. 53 percent of researchers are women and 47 percent are men. 65.6 percent of researchers has doctoral or equivalent degree, 30.1 percent - master's or equivalent degree and 4.2 percent bachelor's or equivalent. The chart below presents the distribution of researchers by level of education and sex [29]. (Daiagram 4)

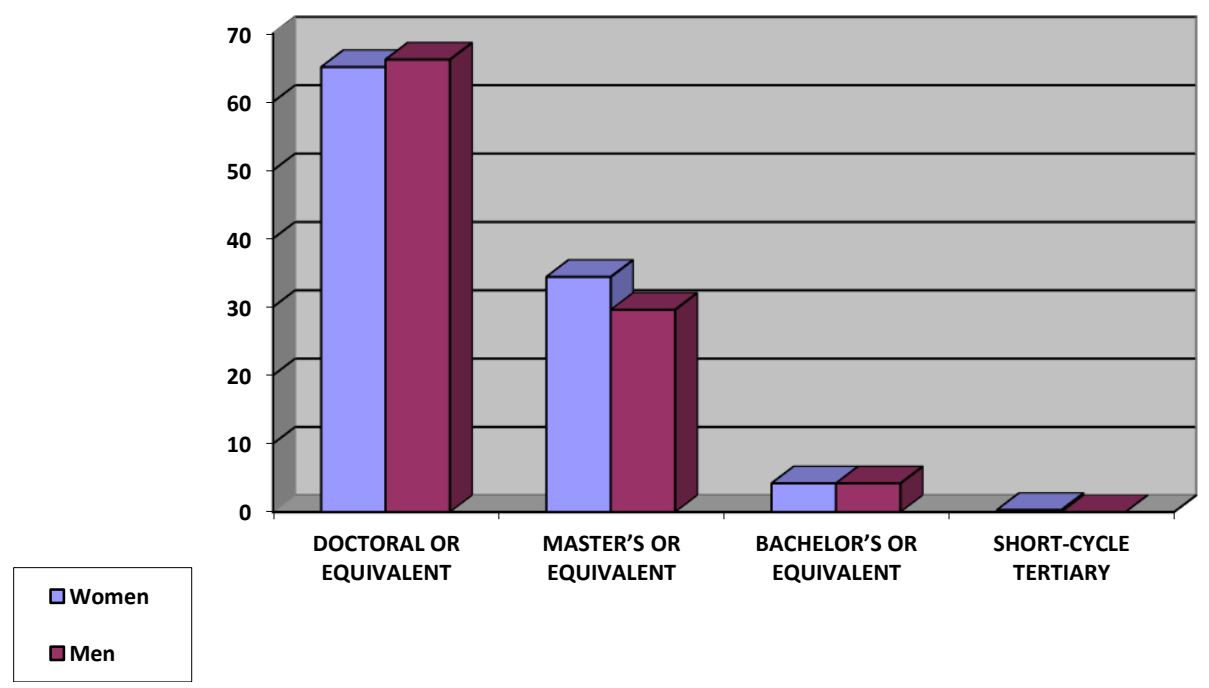

Under the conditions of scarce funding of universities, obtaining research grants are the only way to conduct university research. The main way to get funding from the state is to participate in the grant competition organized by the Shota Rustaveli National Science Foundation (SRNSFG) of the Ministry of Education, Science, Culture and Sport of Georgia. Rustaveli Science Foundation promotes the development of science, technology and innovation systems in the country.

The foundation implements grant calls, targeted programmes and projects is involved in international scientific networks and joint projects. SRNSFG administers more than 20 programmes, out of which 15 national, about 10 international bilateral programmes and 2 multilateral projects (Black Sea Horizon, EaP PLUS) funded by the EU Framework Programme for Research and Innovation "Horizon 2020". The Foundation has an International Advisory Board, which is comprised of leading Georgian and foreign scholars and representatives of the Government of Georgia. The Rustaveli Foundation conducts the scientific grant competitions through an independent, competent commission, thus it is possible to ensure transparency and fairness. However, the disadvantage of funding through exclusively centralized grant competitions is that 
higher education institutions and research institutions have to adapt their research interests to obtain funding for research [30].

The most important activity of the Rustaveli Foundation - funding researches through competitions is not enough for universities to respond to the challenges of the 21 st century. The government should provide universities with sufficient funds for research on the basis of evaluating its productivity and being relevant.

It is also important to actualize and promote the importance of scholarly research not only in private and public higher education institutions and academic circles, but also its importance should be explained to students. A scientific research activity is a top priority for only $10 \%$ of the 1093 surveyed students, for most students - lecture quality (73\%) and other activities adjusted to student needs (17\%) (Kharadze, Natalia; Gulua, Ekaterine;, 2018).

In order to understand students' attitudes to management challenges at public and private higher education institutions, we conducted a pilot study. We interviewed one state (Ivane Javakhishvili Tbilisi State University) and one private (Caucasus International University) undergraduate students at the Faculty of Economics and Business, as they have more learning and interacting experience at university than freshmen.

The study was conducted in 2017 according to the survey questionnaire conducted by the State University (Gulua, Ekaterine, 2017). Both students and academic staff were interviewed then (Gulua, Ekaterine;, 2018) (Gulua, Ekaterine;, 2019).There is a big difference between the scales of these universities, as far as the rankings are concerned, as already mentioned, the ranking of the state university is much higher than of the selected private university.

The study clearly showed the students' attitude - the degree of confidence in their own university. $58 \%$ of the surveyed students at a private university believe that they get a good level of knowledge at their university, while $24 \%$ of students at a state university are definitely positive. $56 \%$ believe that they receive only theoretical knowledge (Diagram 5).

We were interested to see if students thought they would be globally competitive after graduation. Here, their optimism is much lower. $65 \%$ of the surveyed students at the State University think that they receive such knowledge only in some subjects, while $45 \%$ of the students at private universities believe that they receive international knowledge in most subjects. In this regard, $15 \%$ of the surveyed students at the private university and only $4 \%$ of the State University trust fully their own university (Diagram 6).

\section{Diagram 6. Are there subjects in which you acquire international knowledge?}

\section{$\mathrm{TSU}=\mathrm{CIU}$}

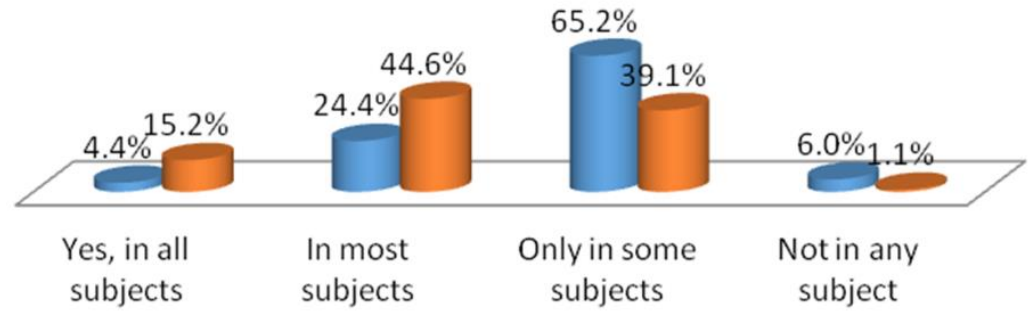

For present-day students it is also prioritised to get practical knowledge, the majority of the surveyed students at private and public universities think they receive such knowledge only partially (Diagram 7). 


\section{Diagram 7. Do you think you are getting the knowledge that you can use or are already using in practice?}

$$
\llbracket \mathrm{CIU} \backsim \mathrm{TSU}
$$

\section{Avoid to answering the question}

No, it is basically useless

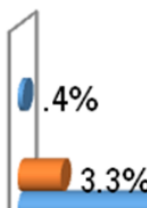

Yes, partly

Yes, I'm satisfied

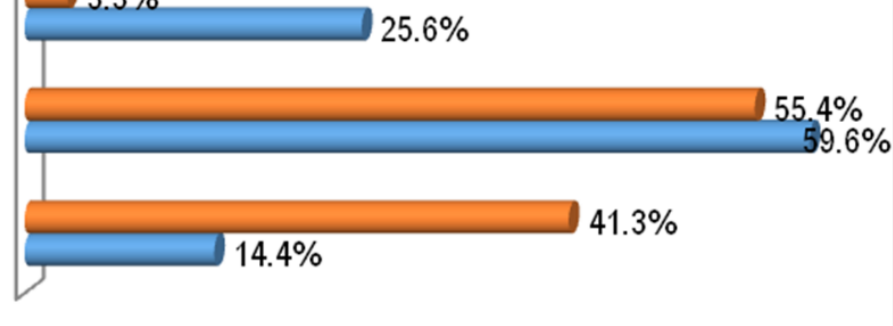

How much do students value their job prospects at the expense of university authority? The interviewed students' positive responses (yes and mostly yes) to this question at private and state universities equaled and amounted to $70 \%$ in both cases (Diagram 8).

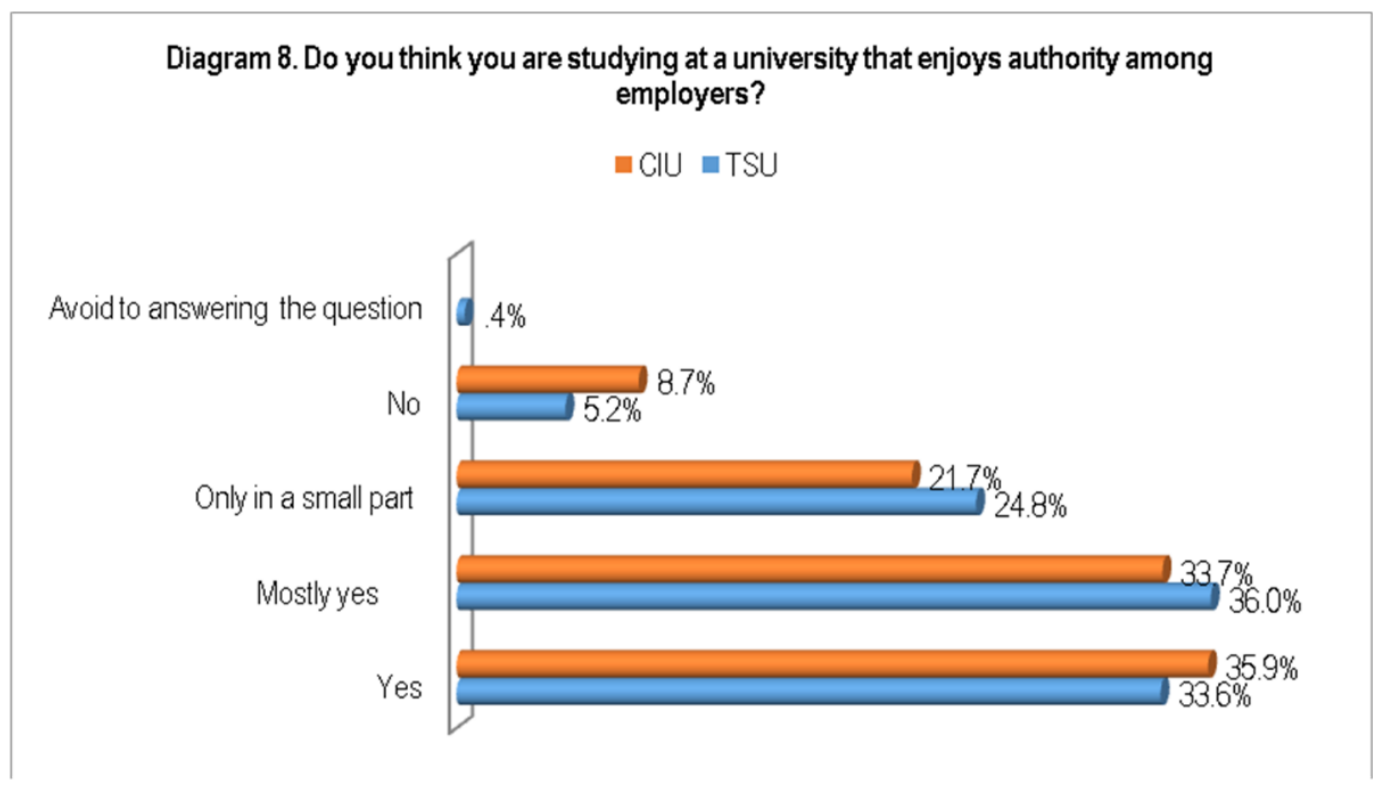

Regarding students' confidence in the qualifications of academic staff - the majority of students (62\%) surveyed at a private university are obviously positive, while $26 \%$ believe that the majority of lecturers are highly qualified. $25 \%$ of the students surveyed at the State University are unequivocally positive about the issue, the majority (51\%) consider the majority of their 
lecturers to be highly qualified. The attitude of $22 \%$ is relatively negative, considering that lecturers are highly qualified only in rare cases (Diagram 9).

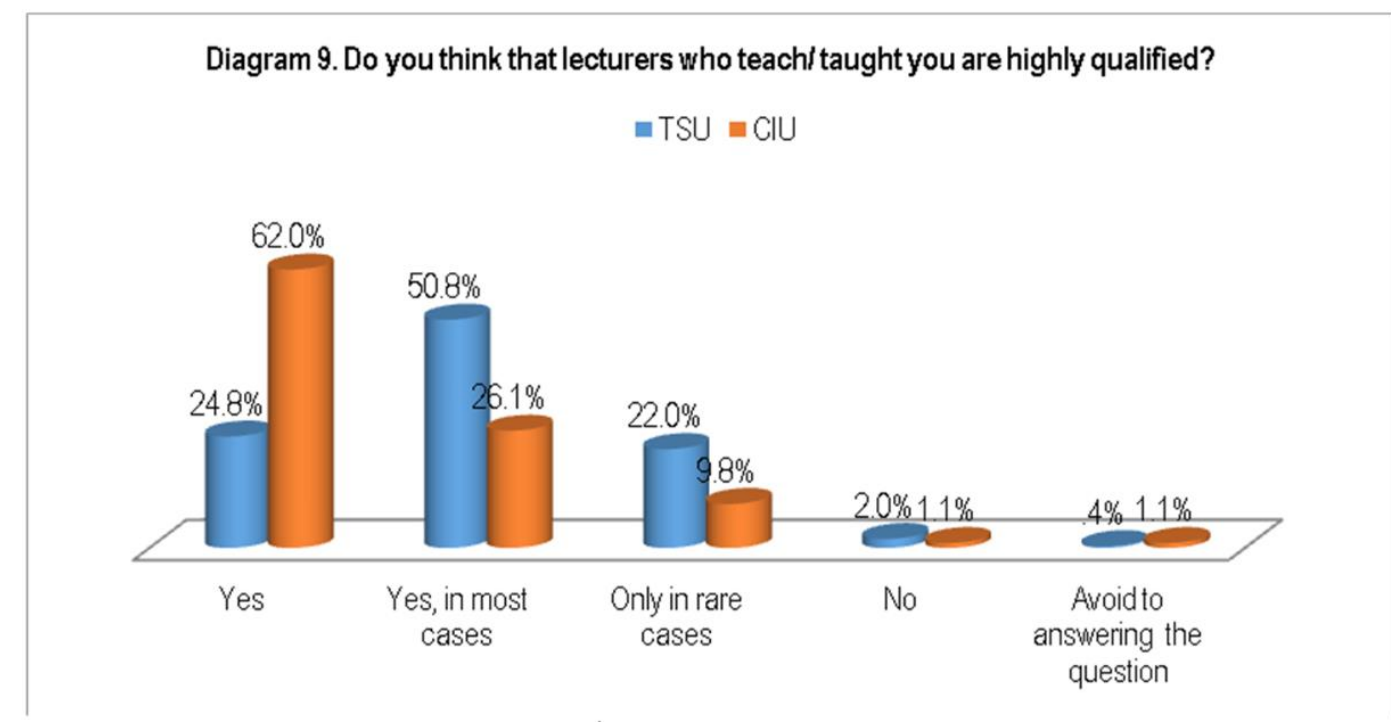

$69 \%$ of the students surveyed at the State University are apparently dissatisfied with their university infrastructure. While the majority $(53 \%)$ of the students surveyed at a private university believes that the Caucasus International University infrastructure is on a high level (Diagram 10).

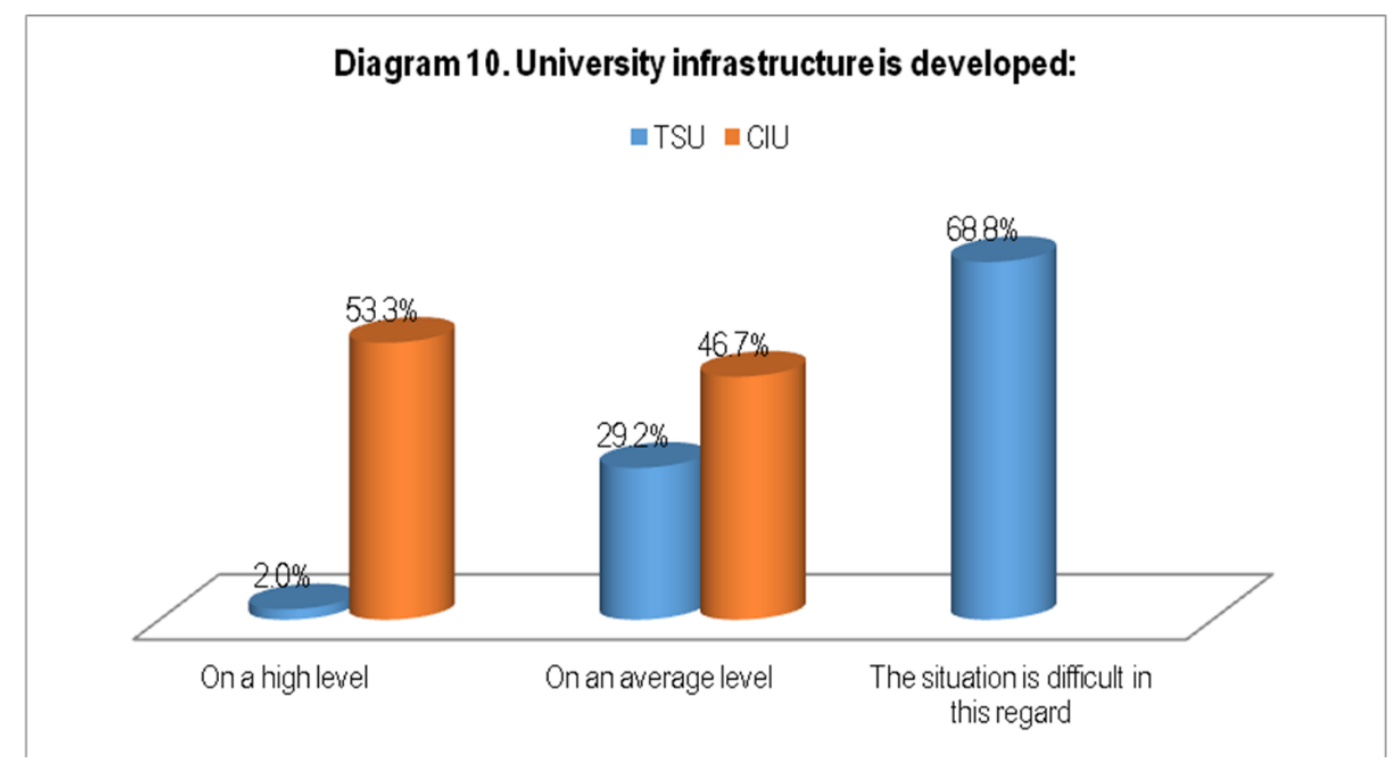

To determine the basics of students' attitudes, we examined how students rated infrastructure elements such as: equipping lecture halls, sports facilities, curriculum software, and so on. 
$90 \%$ of the students surveyed by the State University are dissatisfied with the technical equipment of the lecture halls, they believe that the situation in different lecture halls is unequal, and $80 \%$ of the surveyed students of the private university think that the there are equal working conditions at the faculty (Diagram 11).

\section{Diagram11. Are lecture-seminars, lecture halls provided with equal technical equipment?}

TSU $\mathrm{CIU}$

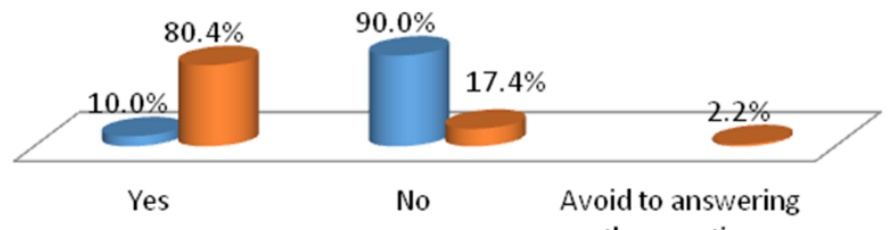

the question

When asked whether there are sports facilities for students, the majority of the respondents (56\%) of the State University consider them insufficient. Most of the students (43\%) surveyed at private higher education institution expressed dissatisfaction in this regard (Diagram 12).

Diagram 12. Are there sports spaces for students at the university?

$\square \mathrm{CIU} \square \mathrm{TSU}$

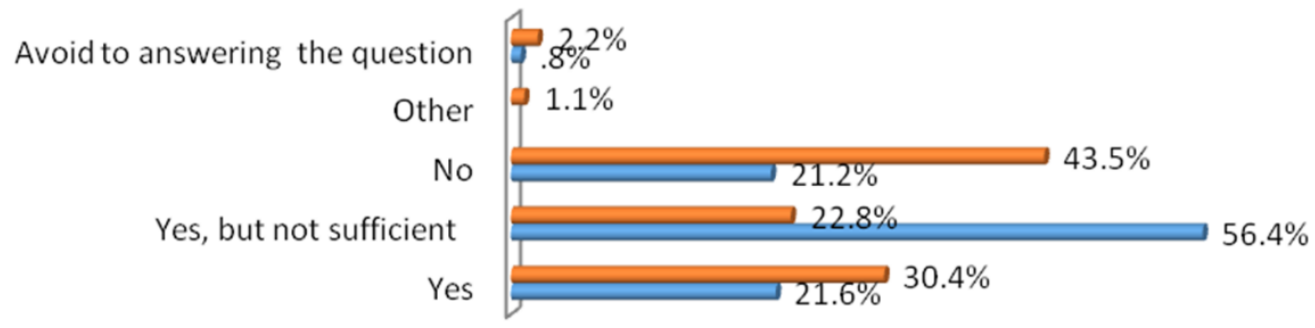

Both in public and private universities students are dissatisfied with entertainment space, with $58 \%$ and $40 \%$, respectively (Diagram 13). 


\section{Diagram 13. Are there entertaining spaces for students at the university?}
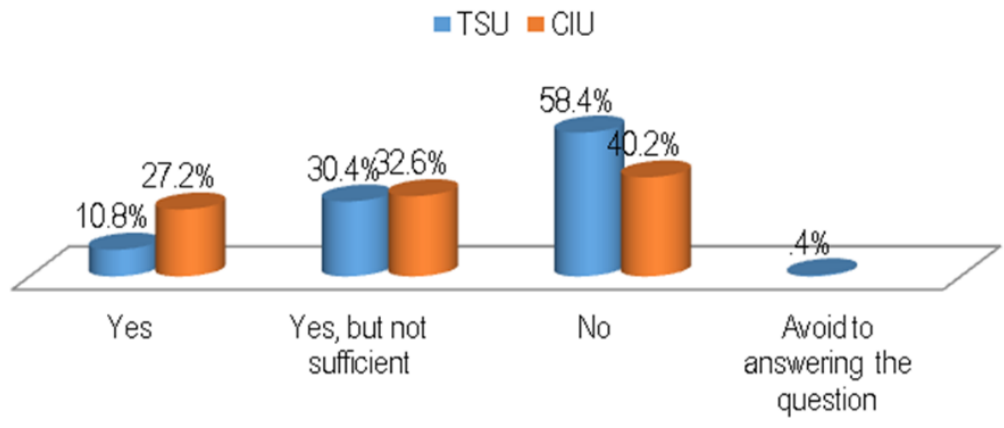

Most students $(88 \%)$ did not, or rarely have problems with electronic databases at a private university. At the State University, 48\% expressed satisfaction (Diagram 14).

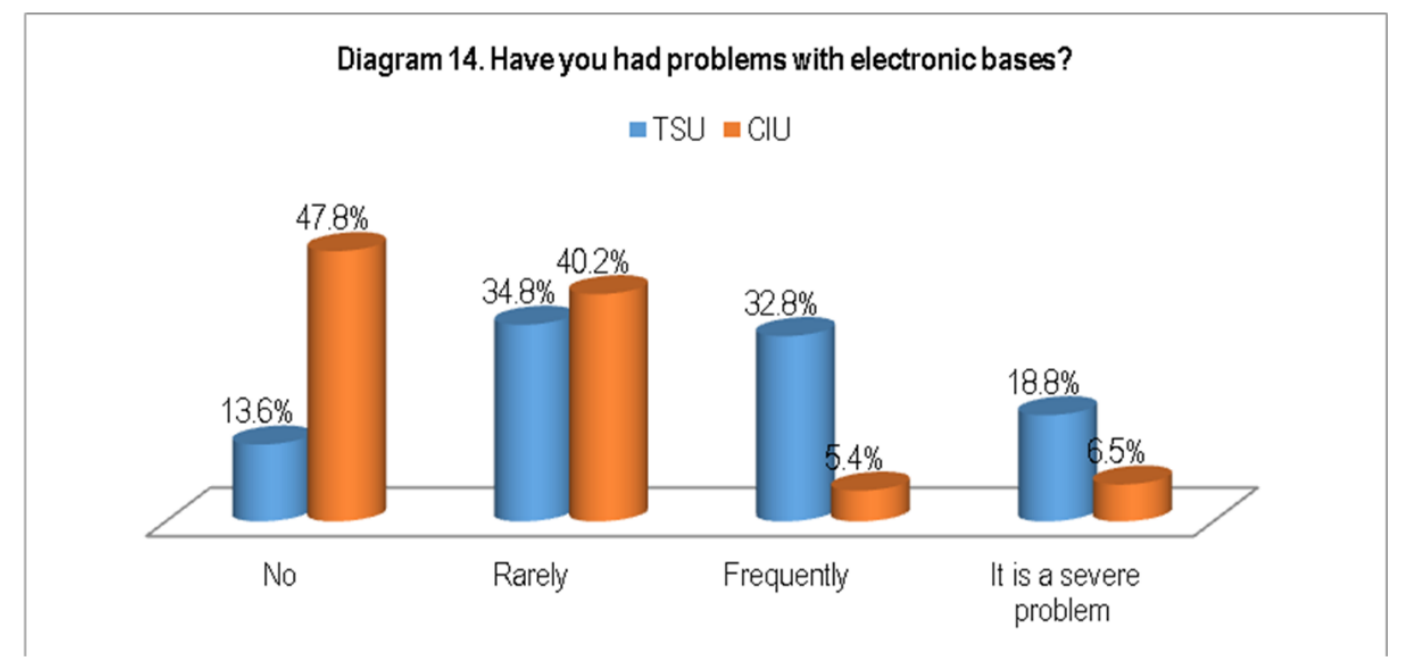

Students perceive it to be problematic when they have to pass more than one midterm or final exam in a day. $45 \%$ of such students were from a private university and $36 \%$ from a state university (Diagram 15). 


\section{Diagram 15. Have you taken more than one exam per day?}

$\because \mathrm{TSU}=\mathrm{CIU}$

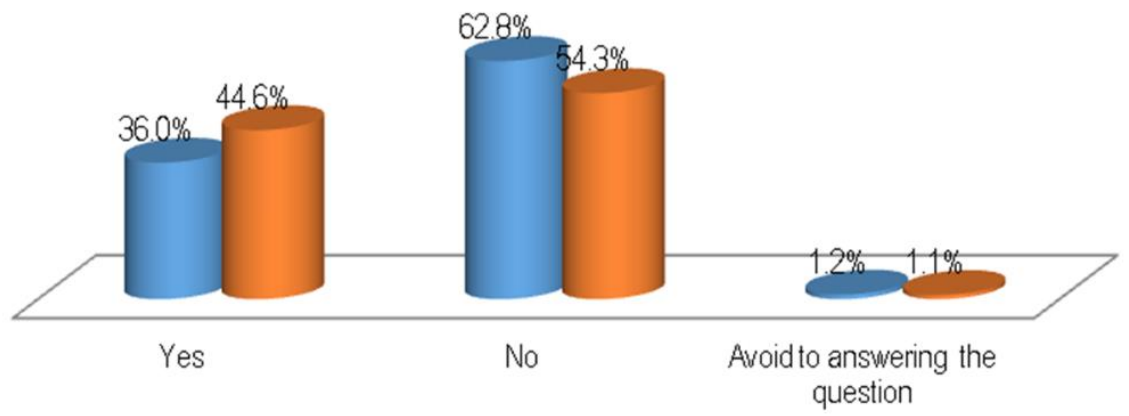

The vast majority (95\%) of the students, surveyed at the Caucasus International University positively assesses the management's role in resolving their problems, $5 \%$ express their dissatisfaction, $61 \%$ of the State University students are positive, and, respectively, $26 \%$ and $11 \%$ think that bureaucratic barriers are significant and this is a severe problem (Diagram 16).

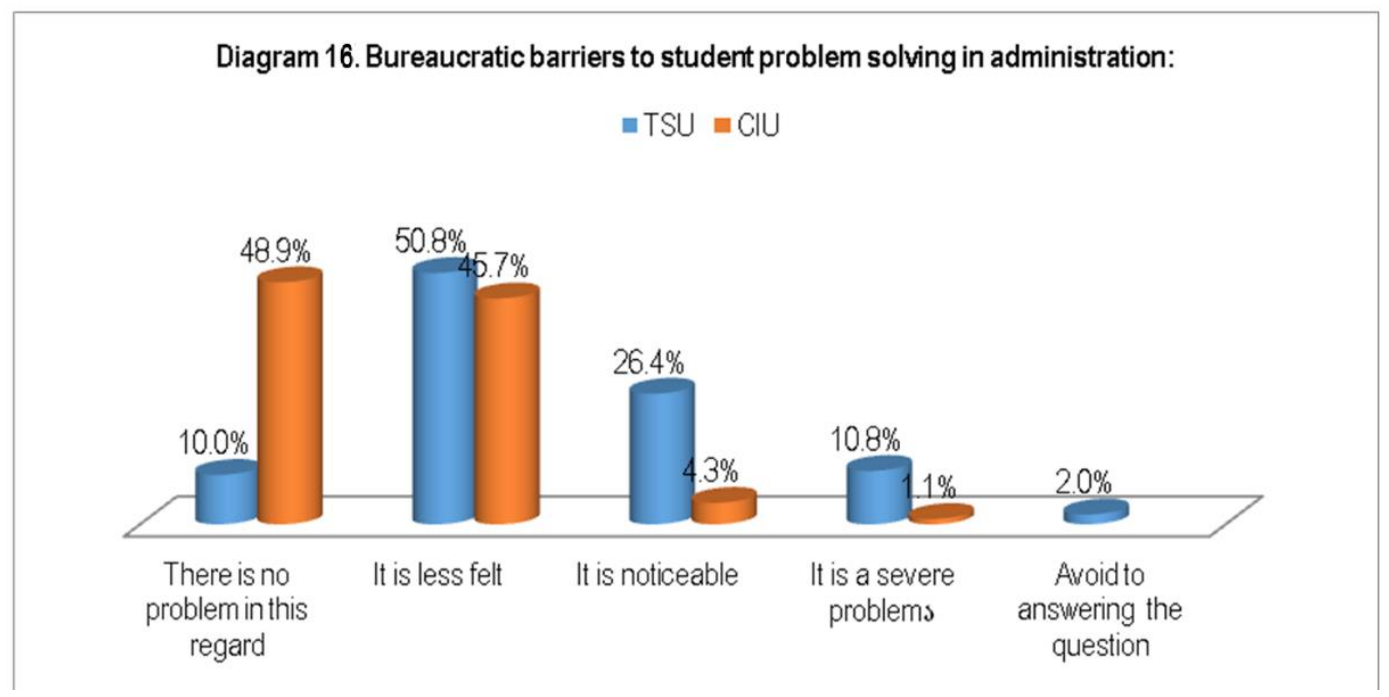

$87 \%$ of the students surveyed at private universities and $51 \%$ of the students interviewed at the State University are satisfied with the support staff of the university administration (Diagram 17). 


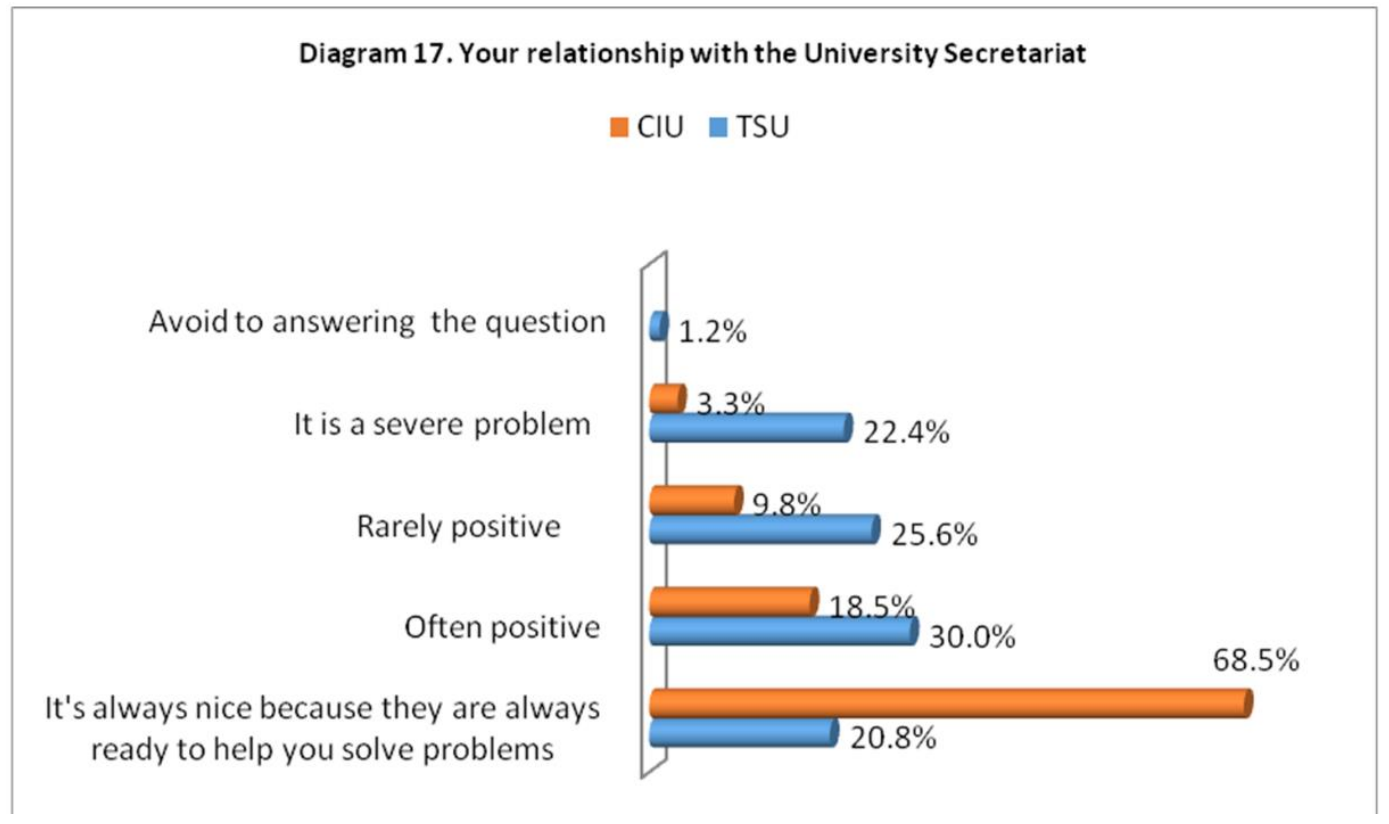

$40 \%$ of the students surveyed at the State University and $67 \%$ at the private university are satisfied with the frequency of events for students (Diagram 18).

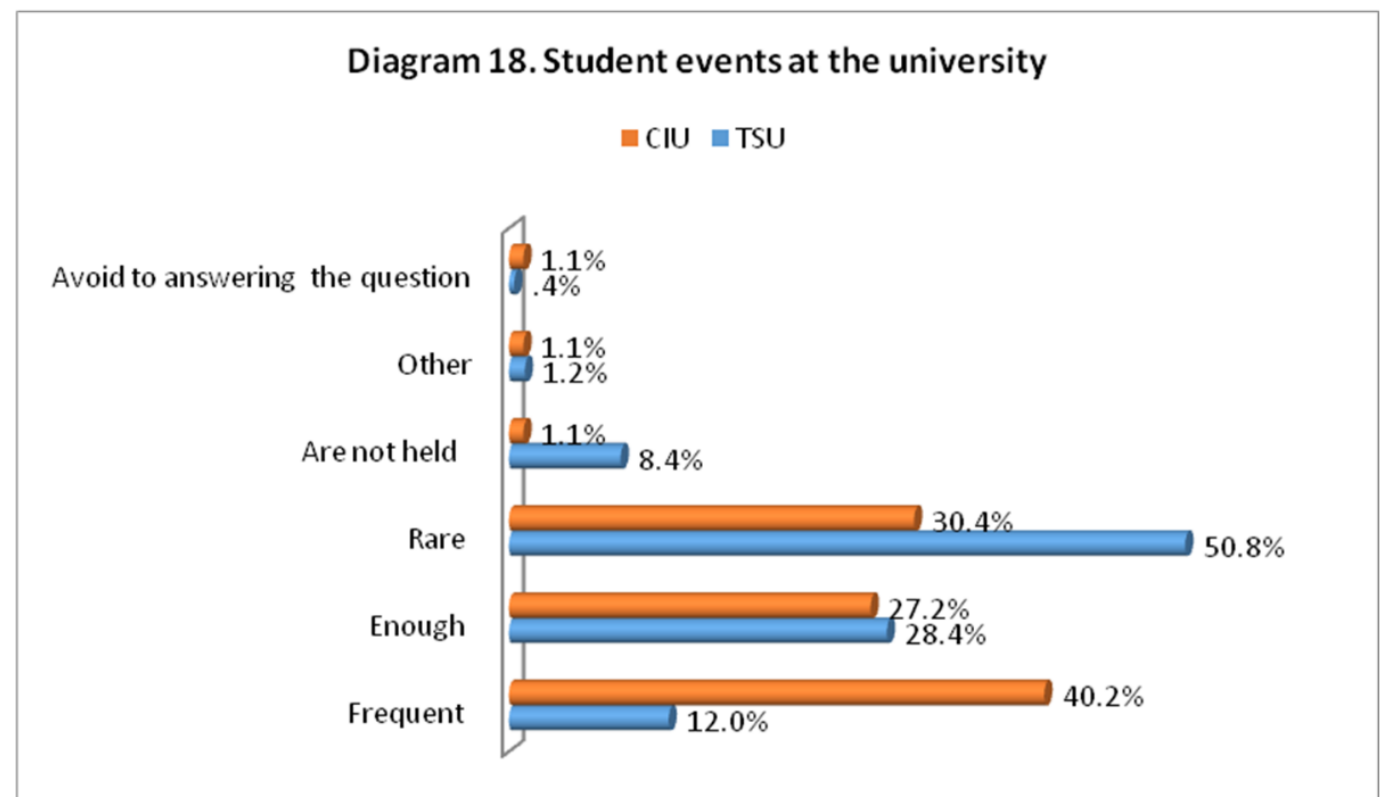

$47 \%$ of the students surveyed at a private university are satisfied with the university student life, $45 \%$ think it is monotonous, $7 \%$ think it is tense, $19.2 \%$ of the state university students think the student life is tense, $58 \%$ think it is monotonous, $28 \%$ think it is diverse and interesting (Diagram 19). 


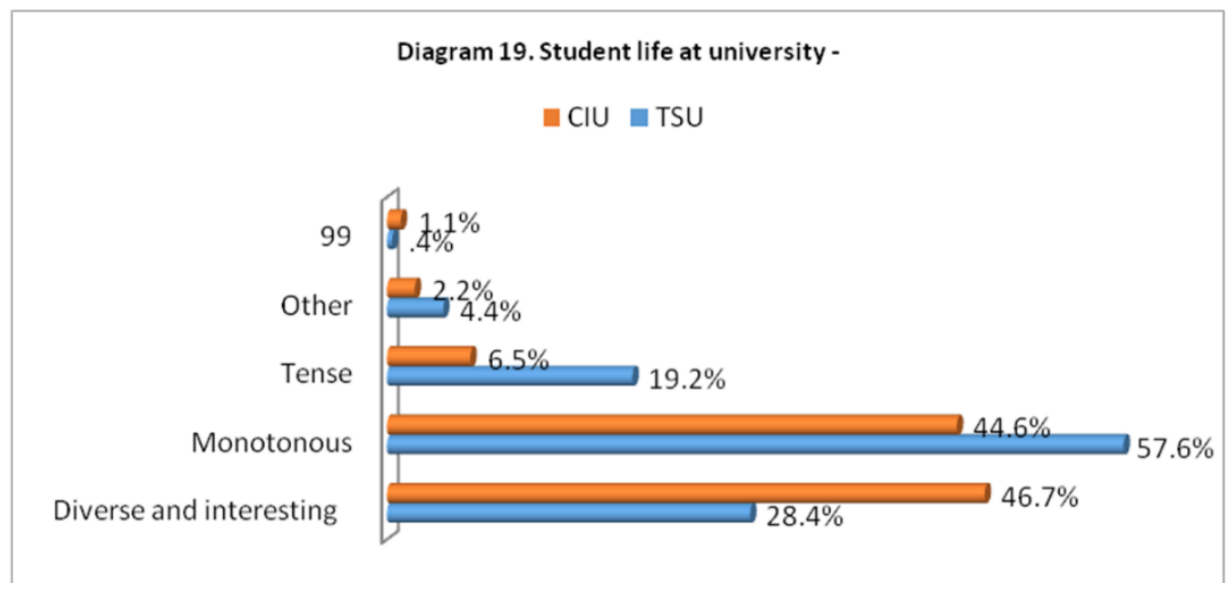

In case of re-election $68 \%$ of TSU students would still choose TSU, $27 \%$ prefer to study abroad, while $22 \%$ from other local universities preferred Free University. $61 \%$ of the students from Caucasus International University think their own university is still a priority for them, some other local universities are in the second place $(12 \%), 14 \%$ would choose Caucasus University from local universities, the choice was equally distributed between TSU and Free University - 6.5\%, the third choice (12\%) is to study abroad (Diagram 20 ).

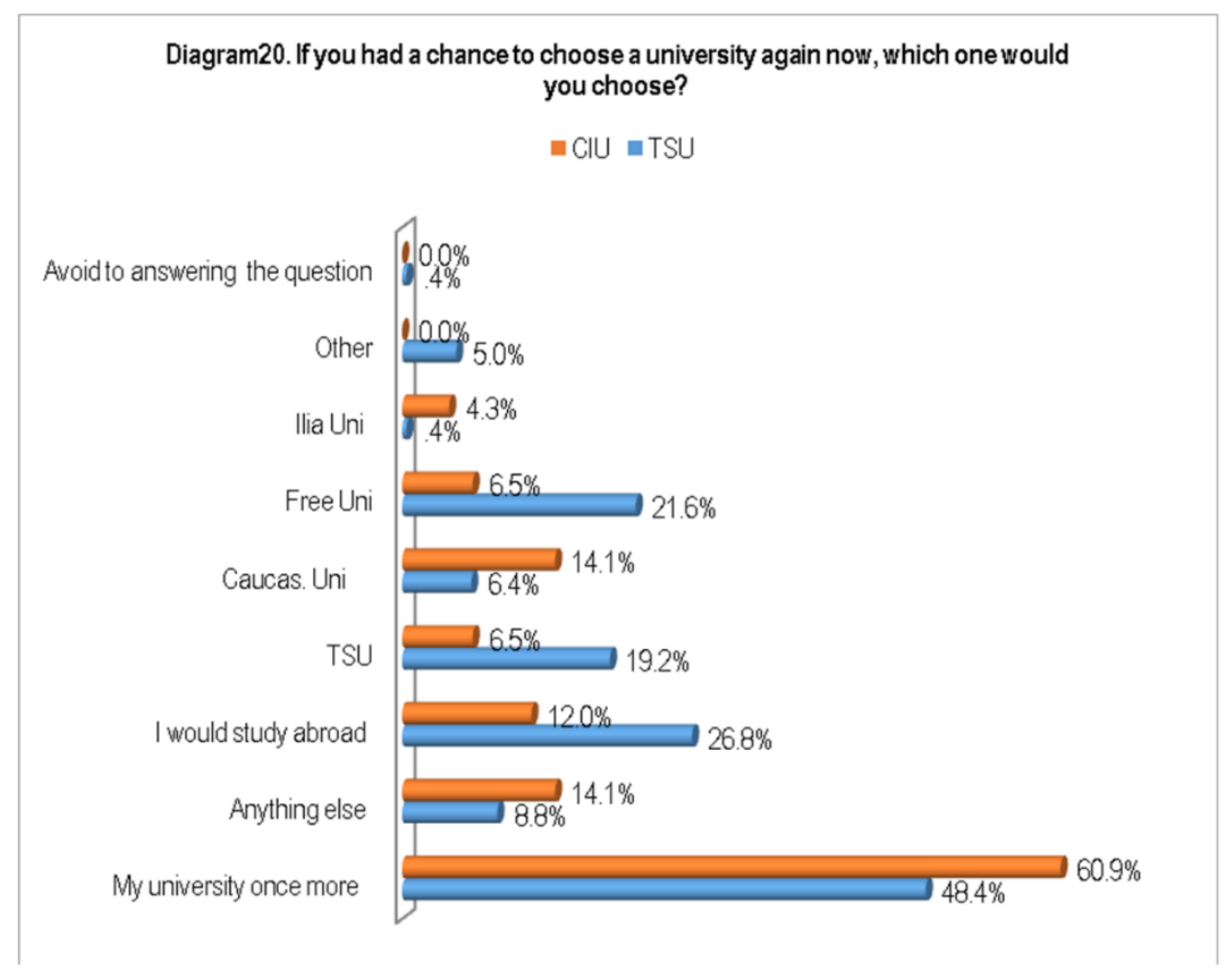

Most students from both universities believe they have made the right choice. $70 \%$ are satisfied with the choice of Caucasus International University and $51 \%$ with TSU, $20 \%$ and $38 \%$ sometimes doubt their decision and $10 \%$ gave a negative answer in both cases (Diagram 21). 


\section{Diagram21. Do you think you have made the right professional choice?}

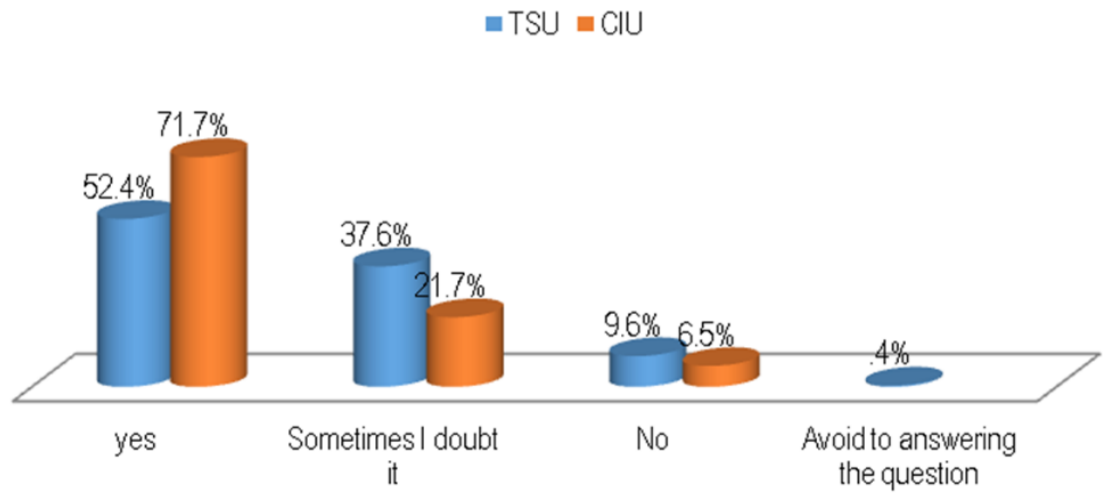

The research has shown that students are largely critical to the State University against the background of the fact that Tbilisi State University is the oldest university in the Caucasus region. There are about 240 educational programs, 16 research institutes, about 85 teaching laboratories; 24 foreign language programs - bachelor's, master's, doctoral and onelevel programs, including bachelor's degree programs with international accreditation; TSU has 22,000 students / more than 900 foreign citizens from 50 countries.

In Georgia, there are obvious positive and negative factors which affect the functioning of private and public universities. The State University, with its large, though outdated infrastructure (Gulua, Ekaterine;, 2019) , is still unable to reform, taking into account the interests of the market, consumers (students) due to the remnants of the Soviet governance. It is not flexible, it has to maintain many directions, programs, institutions or certain categories of staff based on the interests of purely national or traditional interest groups, which is related to high costs and at the same time it is unable to introduce innovations, upgrade infrastructure and make restructuring.

It is necessary for the university to be given real autonomy in addition to formalities, also introducing a democratizing process in the organization, staff (including younger generations of scholars) should become more free, equipped and empowered to contribute to the development of the university. Transparency of processes, improvement of access to information, introduction of a mutual control mechanism can greatly contribute to the advancement of reforms. In the process of university reforms, it is important to take into account the interests of students, employees and employers. The development of a mutually supportive and healthy generational shift mechanism (Gulua, Ekaterine, 2013) is important, as Tbilisi State University has not only a teaching but also a scientific purpose and includes all levels of teaching programs; It is possible to employ young staff at the undergraduate level, and the older ones at doctoral level and at university-affiliated research institutes. The results of the study show that although TSU has some advantages in a number of areas, students do not perceive it properly, so it is important to improve student service systems and also internal PR so that students have more confidence in their choices.

As for private higher education institutions (in particular Caucasus International University), their advantage is greater degree of freedom of decision making and flexibility. Owners' personal interest in the organization success creates more incentives to implement healthy management. Although Caucasus International University is a new higher education institution and occupies a modest place on the local market, including even private ones, the research shows that its students trust and are loyal to their university more than it is at TSU. Because of the small size of the Georgian education market due to the small population, the private higher education institutions are making more efforts to attract both local and foreign students. Unlike public universities, they set their own tuition fees, but in terms of purchasing power, they offer some benefits to local citizens and seek to increase their income by attracting foreign students. Private universities are trying to do more by improving infrastructure, building student spaces to gain more confidence and become competitive in the segment. 
These difficulties make them more flexible, user-friendly, they use resources more efficiently and effectively, and, therefore, a number of private higher education institutions compete heavily with large traditional universities with a traditional image. It is also noteworthy that their positions on the market are still weak due to short-term operating, which is also influenced by the frequent political and economic fluctuations in Georgia (Gulua, Ekaterine, 2012). Therefore, they are still making a great effort to establish their place on the Georgian market.

According to Barbara Sporn (Sporn, Barbara ;, 2003) an orientation from elite to mass higher education, narrow specialization of universities, diversification, union with vocational colleges, the Bologna Declaration and the Unified Standards System promote mobility and internationalization of students and lecturers. The role of the state in the processes of changes and transformation of European universities has changed since the 1990s to make it more effective and efficient.

Finally, a) globalization, internationalization, global competition, b) quality harmonization and opportunity of comparability of programs; $C$ ) the creation of entrepreneurial universities due to marketisation d) the change in the role of the state as a whole is driven by the actualization of new management trends, management systems, techniques and structures of universities. The structure, processes of management, leadership and administration are changing. Since the higher education system is idiosyncratic, it has mutually exclusive goals, a non-standard, possibly anarchic environment, a diverse electorate, uncertain technologies, a defining role for people - their professionalism; It is imperative to change the bureaucracy, collegial and political approaches to adhocracy and its appropriate professional management approaches and styles based on strengthening middle management and leadership. The role of age groups at universities is also increasing and is governed more by corporate principles than by collegial bodies.

The aforementioned accents show the character of the activities to be carried out in higher education institutions of Georgia. The issue of reforming public universities is particularly urgent, as they create a major backdrop for the country on a large scale and encourage private universities to become more competitive. Taking into consideration the issues mentioned in this paper, the implementation of the experience of developed countries in the management of both public and private universities in Georgia will play an important role in the formation of a professional, globally competitive workforce and in the development of the country.

\section{Bibliography}

[1] Antia, Vakhtang;. (2018, December). Economy - oriented Education and the Management Priorities of the State Higher Education Institutions. Economics , pp. 6-17.

[2] (2010). Europe's Universities beyond 2010: Diversity with a Common Purpose. European University Association.

[3] Gulua, Ekaterine;. (2019, January - April). Management of Process and Infrastructure in Higher Education Institution. European Journal of Interdisciplinary Studies, Volume 5, Issue 1. pg , pp. 27-46.

[4] Gulua, Ekaterine. (2012). "The Post-Crisis Contextual Decisions in Business Organisations. Proceedings of the International Scientific-Practical Conference: "Globalization, Contemporary Problems of International Business and Development Trends" (pp. 245-250). Tbilisi: Universal.

[5] Gulua, Ekaterine. (2017 6mol April-June). Modern Challenges of Higher Education. Economics and Business, Business and Economics Refereed and Reviewed International Scientific and Practical Journal of the Faculty of Economics and Business, Ivane Javakhishvili Tbilisi State University, Volume X, N2 , pp. 112132.

[6] Gulua, Ekaterine. (2013, March-April). Talent-Management - Actual Direction of Human Potential Management. "Economics and Business"- International Refereed and Reviewed Scientific and Practical Journal of the Faculty of Economics and Business, Ivane Javakhishvili Tbilisi State University, N2, , pp. 85-98.

[7] Gulua, Ekaterine;. (2018, Jul 24). Challanges of Higher Education Learning and Scientific Research Process Management. European Journal of Multidisciplinary Studies, Volume 3. Issue 3, pp. 80-100.

[8] Kasradze Tea. (2014). Investment Environment in Georgia and and Domestic Investment Potential of the Country. International Scientific-Analytical Journal Ekonomisti \#5, pp. 33-43.

[9] Kasradze Tea2016Public Finance Management Reform in Georgia and Its Compatibility with the EU practice The works of the International Scientific Conference: European Union Association Agreement:legal, political and economic aspectsTbilisiCaucasus International University 
[10] Kasradze Tea2014The Major Policies Used by the Governments of Developing Countries for Attracting Direct InvestmentsJournal Caucasus International University HERALD \#6

[11] Kasradze Tea2018Trends of Financing for Development in GeorgiaAmerican Scientific Journal \#21 32-40

[12] Kasradze Tea; Zarnadze NinoEnhancing Workforce Competitiveness through Improving Quality of Education - An Indispensable Means for Overcoming PovertyInternational Journal of Innovative Technologies in Economy 19-21

[13] Kasradze, Tea; Antia , Vakhtang; Gulua, Ekaterine;. (2019, January - April Volume 5, Issue 1). Challenges of Financial Management of the Higher Education Institutions in Georgia. European Journal of Economics and Business Studies, , pp. 187-206.

[14] Kharadze, Natalia; Gulua, Ekaterine;. (2018, Volume 5). Analyze of Students' Attitude Survey of Professor Evaluation Criteria. Journal Innovative Economics and Management , pp. 122-131.

[15] Olda, R. (2007). A case study of governance of higher education in Belize: Implications for finance and curricula in higher education. Hoare University of South Florida.

[16] Sporn, Barbara ;. (2003). Management in Higher Education: Current Trends and Future Perspectives in European Colleges and Universities. Springer.

[17] Tea Kasradze, Nino Zarnadze. (2019). CHALLENGES OF ECONOMIC OF GEORGIA: GOOD AND BAD ECONOMIC GROWTH. European Journal of Economics and Business Studies , 178-186.

[18] Tea, Kasradze2013Poverty - A Global Socio-Economic ProblemCaucasus International University HERALD \#5 15-18

[19] HYPERLINK "https://www.scup.org/resource/trends-for-higher-education-spring-2020/" https://www.scup.org/resource/trends-for-higher-education-spring-2020/

[20] HYPERLINK "https://eua.eu/about/member-directory" https://eua.eu/about/member-directory

[21] HYPERLINK "https://www.geostat.ge/media/18181/umaglesi-ganatleba-\%28geo\%29_2019.pdf" https://www.geostat.ge/media/18181/umaglesi-ganatleba-\%28geo\%29_2019.pdf

[22] HYPERLINK "http://www.naec.ge" www.naec.ge

[23] HYPERLINK "https://www.oecd.org/site/worldforum/33703760.pdf" https://www.oecd.org/site/worldforum/33703760.pdf

[24] HYPERLINK "http://www.ces-munich.de/DocDL/dicereport0404forum7.pdf?fbclid=IwAR2Kmw4m4WD4p6P7Yk4ZfiRkPciO1sYugkSzBT1qOg64mrG4cd0QJHWNN0Q" http://www.ces-munich.de/DocDL/dicereport0404forum7.pdf?fbclid=IwAR2Kmw4m4WD4p6P7Yk4ZfiRkPci01sYugkSzBT1qOg64mrG4cd0QJHWNN0Q

[25] HYPERLINK "https://matsne.gov.ge/ka/document/view/32830?publication=79" https://matsne.gov.ge/ka/document/view/32830?publication=79

[26] HYPERLINK "http://erasmusplus.org.ge/files/files/Strategic_Development\%20_of_HE_and_Science_in_Georgia-ge.pdf" http://erasmusplus.org.ge/files/files/Strategic_Development\%20_of_HE_and_Science_in_Georgia-ge.pdf

[27] HYPERLINK "https://matsne.gov.ge/ka/document/view/16270?publication=33" https://matsne.gov.ge/ka/document/view/16270?publication=33

[28] HYPERLINK "http://erasmusplus.org.ge/files/files/Strategic_Development\%20_of_HE_and_Science_in_Georgia-ge.pdf" http://erasmusplus.org.ge/files/files/Strategic_Development\%20_of_HE_and_Science_in_Georgia-ge.pdf

[29] HYPERLINK "https://www.geostat.ge/media/26779/Research-and-Development_2018.pdf" https://www.geostat.ge/media/26779/Research-and-Development_2018.pdf

[30] HYPERLINK "https://www.tsu.ge/data/file_db/xarisxis_martvis_dep/ganatlebis-politika-2.pdf" https://www.tsu.ge/data/file_db/xarisxis_martvis_dep/ganatlebis-politika-2.pdf 